\title{
Original Research \\ Medication storage and self-medication behaviour amongst female students in Malaysia
}

Sohair E ALI, Mohamed I. M. IBRAHIM, Subish PALAIAN.

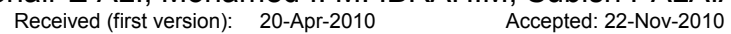

\begin{abstract}
${ }^{\star}$
Objectives: The aims of this study are to determine the prevalence, attitudes and behaviours of medication storage and self-medication amongst female students at Universiti Sains Malaysia (USM). Methods: A cross-sectional survey was conducted and cluster random sampling technique was used for respondent selection. A pre-piloted questionnaire was administered to female respondents so as to collect the data. Data was analyzed using SPSS version 12 and analysis was conducted using descriptive analysis procedures. Results: Of the 481 participants (mean age; SD was $22.1 ; 3.3), 93.1 \%(n=448)$ students stated that they stored medicine in their rooms, while $70.7 \%(n=340)$ stated that they stopped taking a prescribed medicine without consulting a doctor. The prevalence of self-medication was $80.9 \%(n=389)$. The most common reasons for self-medication were related to their knowledge of their ailment and its treatment $(58.0 \%), 14.4 \%$ thought it saved time and $8.5 \%$ mentioned that medication given by provider was not effective. The most common symptoms were otorhinolaryngology problems $(22.5 \%)$, followed by respiratory disease $(19.6 \%)$, Gastro Intestinal Tract (GIT) disease (18.1\%) and headache/fever $(16.8 \%)$. Commonly used medicines were analgesics \& antipyretics $(30.2 \%)$, ear, nose \& throat drugs $(10.8 \%)$, vitamins \& minerals $(10.8 \%)$, GIT drugs $(8.5 \%)$, anti-infections $(7.3 \%)$ and herbal medicines $(3.5 \%)$. Prevalence of medicine storage and self-medication practice is high among educated female students in USM. Conclusions: There is a need to educate the students to ensure safe practice by increasing their awareness. Strict policies need to be implemented on the unrestricted availability of medicines so as to prevent the wastage of medicines.
\end{abstract}

Keywords: Self Medication. Health Knowledge, Attitudes, Practice. Malaysia.

"Sohair E. ALI. MSc. Discipline of Social and Administrative Pharmacy. School of Pharmaceutical Sciences, Universiti Sains Malaysia. Penang (Malaysia). Mohamed I. M. IBRAHIM. PhD. Professor of Social \& Administrative Pharmacy. Department of Pharmacy Practice. College of Pharmacy, Qassim University. Buraidah, Al Qassim (Saudi Arabia).

Subish PALAIAN. PhD. Associate Professor of

Pharmacology. College of Medical Sciences. Bharatpur (Nepal).

\author{
ALMACENAMIENTO DE MEDICACIÓN Y \\ COMPORTAMIENTOS EN AUTO- \\ MEDICACIÓN ENTRE MUJERES \\ ESTUDIANTES EN MALASIA
}

\section{RESUMEN}

Objetivos: Los objetivos de este estudio son

determinar la prevalencia, actitudes y

comportamiento en el almacenamiento de

medicamentos y la auto-medicación entre mujeres

jóvenes estudiantes en la Universiti Sains Malaysia (USM).

Métodos: Se realizó un estudio transversal y se utilizó una técnica de muestreo por cluster para la selección de respondentes. Para recoger los datos, se administró un cuestionario pre-pilotado a las mujeres que respondieron. Los datos fueron analizados utilizando el SPSS versión 12 y el análisis se realizó utilizando procedimientos descriptivos.

Resultados: De los 481 participantes (edad media; DE era 22,$1 ; 3,3)$, el $93,1 \%(n=448)$ afirmaron que almacenaban medicamentos en sus habitaciones, mientras que el $70,7 \%(n=340)$ afirmó que pararon de tomar un medicamento prescrito sin consultar al médico. La prevalencia de auto-medicación era del $80,9 \%(n=389)$. Entre las razones más frecuentes para auto-medicación estaban relacionadas con sus conocimientos de su enfermedad y su tratamiento $(58,0 \%)$, el $14,4 \%$ pensaba que ahorraba tiempo y el $8,5 \%$ mencionó que la medicación proporcionada no era efectiva. Los síntomas más frecuentes fueron problemas otorrinolaringológicos $(22,5 \%)$, seguidos de enfermedades respiratorias $(19,6 \%)$, del tracto gastrointestinal (TGI) $(18,1 \%$ y dolor de cabeza/fiebre $(16,8 \%)$. Los medicamentos frecuentemente utilizados eran analgésicos y antipiréticos $(30,2 \%)$, medicamentos para nariz, garganta y oídos $(10,8 \%)$, vitaminas y minerales $(10,8 \%)$ y plantas medicinales $(3,5 \%)$. La prevalencia del hábito de almacenar medicamentos y de auto-medicación es alta entre las mujeres estudiantes de la USM.

Conclusiones: Existe la necesidad de educar a los estudiantes para garantizar la práctica segura aumentando sus conocimientos. Se necesita implantar políticas estrictas sobre la disponibilidad irrestricta de medicamentos así como para prevenir el desperdicio de medicamentos.

Palabras clave: Auto-medicación. Conocimiento, actitudes y práctica en salud. Malasia. 


\section{INTRODUCTION}

Inappropriate use of medicines is a prominent constraint in ensuring the safe and effective use of essential medicines. The increase in the quantities and varieties of pharmaceuticals worldwide eases the accessibility of medicine by consumers and thereby giving options for misuse. If it followed with inappropriate use, this will lead to health risk and economic burden to government and decrease the affordability of medicine to patients. ${ }^{1,2}$ Self medication is defined as the activity of obtaining and consuming drugs without the advice of a physician either for diagnosis, prescription or surveillance of treatment. This includes acquiring medicines without a prescription (OTC), sharing medicines with relatives or friends or using left-over medicine stored at residential place. ${ }^{3}$ Few studies have shown that self-medication practices are more common in women of a younger age and among students as well. ${ }^{4,5}$

Self-medication may lead to inappropriate use of medicines. The World Health Organization (WHO) ${ }^{6}$, reported that sub-optimal prescribing practices such as inadequate dosing, incomplete treatment courses and indiscriminate drug use have contributed to the emergence and spread of antimicrobial resistance. The prevalence of selfmedication amongst university students in previous studies was found to be about $76 \%$ in Karachi, Pakistan ${ }^{7}, 45 \%$ in Turkey 8 , $88 \%$ in Croatia $^{9}$, and $94 \%$ in Hong Kong. ${ }^{10}$ Several studies of pharmaceutical practice have been conducted over the last two decades by pharmacoepidemiologists, health social scientists, etc. These studies have examined the clinical rationality of prescription practices (include excessive and irrational prescribing), self-medication inclusive of over-thecounter (OTC) drug use for acute and chronic illnesses, poor compliance to prescriptions and storage of medicine. ${ }^{11-14}$ During reviewing many studies, existing interventions aiming at improving drug use from a medical as well as a consumer perspective are few. The stocking of medicines at students' rooms and obtaining of prescription onlydrugs directly from the university private community pharmacies (PCP) are the expected major factors behind self-medication practices among students in Universiti Sains Malaysia (USM). The first factor carries the risk of exposing medicine to expiration, sharing medicine with friends, taking medicine that have been originally prescribed for different problem or even accidental drug poisoning, while the second factor carries the risk that if dispensing medicine is not followed by appropriate explanation by pharmacists at the moment of consultation, it will be hazardous to patients' lives.

The total number of patients with specific diseases who visited the USM Health Centre (the centre that takes care the healthcare needs of nearly 15,000 populations) during 2002 had increased by approximately $11 \%$ from 2001 . The ratio of students in the university is 70 females to 30 males; the ratio attending the health care center is 60 females to 40 males. The estimated total cost of drugs in Malaysian Ringgit spent for the treatment of different pharmacological cases amount to RM360,606.82 (USD 107005) (USD1=RM 3.37 in the year 2005). In the period from January 2001 to March 2003, the amount of money expended on medicines by the Health Centre and its pharmacy for students alone totalled RM 70,931.16 (USD $21047){ }^{15}$ This places a heavy financial burden on the USM health system with annual increase of students' intake. Thus, the prevalence of drug misuse (drug storage and self-medication practices) if not contained will further aggravate the financial situation to the health system by resulting in huge drug wastage and health risks. Cognizant of this fact, a study was conducted through a crosssectional survey of USM female students which aimed at identifying students' behavioural aspects and attitudes towards drug usage (medication storage and self-medication practices). The aims of this study were to obtain baseline information on the extent of medication storage and self-medication behaviours among female students in USM, and to obtain information on the reasons behind selfmedication practice.

\section{METHODS}

Study design: A descriptive, cross-sectional study design was chosen as the means to investigate the medication storage and self-medication behaviours amongst female students in the USM main campus. Data were collected by visiting the students in their rooms and through face-to-face interview.

Study location: USM is the second oldest and one of the four universities in Malaysia that have been earmarked as research-intensive universities. It has 3 campuses and the study was conducted in the main campus in the state of Penang. The main health care services are provided by the USM Health Centre. The centre opens from 8:00 AM to 5:00 PM and 7:00 PM to 9:00 PM. In addition, healthcare services are also provided to the students, staffs and dependants by the panel private clinics and pharmacies that are linked with the university for a period of two years (renewable).

Study sample: In the year 2005, about 30,000 students were enrolled in USM. The total number of students in the main campus in the same year is about 23,269 students with male students accounted totally to about 8,894 and female students amounting up to 14,375 . The study was conducted during February to June in 2005. Using specific sample size equation,

$$
\frac{Z^{2} *(p) *(p-1)}{C^{2}}
$$

a sample of 530 students was selected. A two stage random sampling technique was used. Stage 1 involved the selection of the relevant hostels (female students' residential areas) through simple random sampling and stage 2 involved the selection of female students from these selected hostels and 
was drawn from within these clusters using the same random sampling procedure. After explaining the purpose of the study, students gave written consent to participate in the study. The questionnaires were completed in the presence of the researcher in case respondents required assistance.

Data collection: Data were collected using a structured pre-piloted questionnaire containing both closed-and open-ended questions. The questionnaire includes questions on demographic information, students' behaviours and attitudes towards self-medication practices, students' health status and health services provided to the students by USM, sources of information on medicines, reasons for self-medication and medication storage. The respondents were asked to provide additional information regarding the storage habits of their medications and were inquired about if they encountered any accidental drug poisoning. The questionnaire was pilot-tested for content and design on 30 female students and modifications were made as necessary.

Study approval: The study was approved by the USM School of Pharmaceutical Sciences' Postgraduate Studies Board and management of the university. Written consent was obtained from the respondents.

Data analysis: Data were entered into statistical package for Social Sciences (SPSS version 12) and descriptive analysis was conducted as follows: quantitative data was processed and analysed using frequencies, means, standard deviation (SD), medians and cross-tabulation. Apart from this, appropriate non-parametric statistical tests were utilised for skewed data, and where applicable, to establish relationships or differences between variables. Kruskal Wallis test was carryout for significant difference between amount of money spent and ethnic as well as the years of study. Data normality was tested by using probability plot (P-P plot). The statistical significance level (alpha) was 0.05 with confidence interval of $95 \%$.

\section{RESULTS}

Altogether, 481 female students completed the questionnaire giving a response rate of $90.76 \%$. Respondents' ages varied from 19 to 54 years. Majority $(n=429 ; 89.2 \%)$ of the students were categorised in the 19-24 years age category. Mean age was $22.1(S D=3.3)$. Slightly more than half $(n=$ $263 ; 54.7 \%$ ) of the respondents were of Malay ethnic origin while $30.8 \%(n=148)$ of Chinese origin. Other ethnic origins were non-Malay indigenous groups and students of Arab, Indonesian, Thai, Bangladeshi and Pakistani origins.

Of the total 481 female students, almost one forth $(n=118 ; 24.5 \%)$ of the undergraduate respondents were from the first year cohort while $23.5 \%(n=113)$ were from the second year cohort, followed by $16.6 \%$ from third year, $12.1 \%$ from fourth year, $1.3 \%$ from $\mathrm{PhD}$ and $0.2 \%$ were others.
Majority of the students ( $n=448 ; 93.1 \%)$ kept medicines in their rooms. Slightly more than one third $(n=180 ; 37.4 \%)$ of the respondents comprehensively understood the symptoms or the indications that prompted the use of the stored drugs. In contrast, $45.7 \% \quad(n=220)$ of the respondents knew only some of the symptoms that required the use of the stored medications while $16.8 \%(n=81)$ revealed total ignorance of the symptoms that required the use of the stocked medications. Regarding the precautions taken prior to drug administration or ingestion, $28.5 \% \quad(n=137)$ revealed that they always checked on the expiry dates prior to use while $53.8 \% \quad(n=259)$ disclosed that they sometimes did so. Only 6.9\% $(n=33)$ mentioned that they did not check the expiry dates prior to usage. More than three fourth $(n=317$; $77.1 \%$ ) of the respondents mentioned that they stocked medications in their rooms (in their original prescribed amount) for emergency use. In contrast, $22.9 \%(n=110)$ did not store any medications for the same purpose. Table 1 reveals the different types of medicine stocked by female students for emergency purposes. The total number of medicines obtained from USM Health Centre alone constituted $71.4 \%$ $(n=1231)$ of the overall total of medicine with an estimated cost of RM8820.40.

\begin{tabular}{|l|c|}
\hline \multicolumn{2}{|l|}{ Table 1. Extent of medicine storage $(\mathrm{n}=481)$} \\
\hline $\begin{array}{l}\text { Types of medicines stocked by female } \\
\text { students for emergency purposes }\end{array}$ & $\mathrm{N}(\%)$ \\
\hline Analgesics \& antipyretics & $145(30.2 \%)$ \\
\hline ENT drugs & $52(10.8 \%)$ \\
\hline Vitamins \& minerals & $52(10.8 \%)$ \\
\hline GIT drugs & $41(8.5 \%)$ \\
\hline Anti-infections & $35(7.3 \%)$ \\
\hline Herbal medicine & $17(3.5 \%)$ \\
\hline Respiratory system drugs & $15(3.1 \%)$ \\
\hline Skin products & $11(2.3 \%)$ \\
\hline Other*medicines & $3(0.6 \%)$ \\
\hline No medicine stocked & $110(22.9 \%)$ \\
\hline $\begin{array}{l}* \\
\text { *Other (Cardiovascular drug, Genito-urinary drug \& eye } \\
\text { drops) }\end{array}$ \\
\hline
\end{tabular}

When the female students asked about the reason behind stocking this type of medicine specifically, $30.1 \%$ mentioned that they need 'pain killers' every month, $14.6 \%$ mentioned they need vitamins for their study, $22.0 \%$ declared that they usually use this sort of medicines for their disease and lastly $10.4 \%$ said that they keep whatever medicine for future use.

The study also investigated where the medications were stored and the manner in which they were stored. Slightly more than half $(n=282 ; 58.7 \%)$ of the respondents stored their medicines in cupboards while $26.6 \%(n=128)$ of the respondents kept their medicines on wall shelves. Other places of storage included drawer, the refrigerator, bathroom, as well as in cars. In terms of packaging, $88.6 \% \quad(n=426)$ of the respondents kept their medicines in their original package while a very small percentage $(n=9 ; 1.8 \%)$ of the respondents did not retain the original packaging. In terms of disposal of medicine, $73.2 \%(n=352)$ of the students surveyed got rid of their expired medications by throwing them into the rubbish bin, while $22.5 \%$ $(n=108)$ of the students keep their medicines to be 
reused if unexpired. As for accidental drug poisoning, $91.7 \%(n=441)$ of the respondents did not report any case of drug poisoning. However, $8.3 \%(n=40)$ of the students claimed that they experienced cases of accidental drug poisoning.

The study also examined female students' behaviours of self-medication practice and found that the prevalence of self-medication among female students was $80.9 \%(n=389)$.

Overall, $85.0 \%$ of the respondents requested for over the counter (OTC) medications or prescription only drugs during their visits to the private clinics and pharmacies to treat minor ailments. The estimated median amount of money expended by a student in purchasing over the counter remedies or few prescription only drugs per semester was RM12.00 (USD 3.56) with the maximum amount being expended totalling RM300.00 (USD 89.02). Overall, the 481 respondents surveyed spent a gross amount of RM 12,364.00 (USD 3668) to purchase OTC drugs while $60.9 \%(n=293)$ of the respondents paid between RM1 to RM50. There was a significant difference $(p=0.002)$ between the amount of financial resources expended on OTC medicines based on ethnicity; Malay students spent more money for purchasing OTC medicines than students of other ethnicity. In addition, there was a significant difference $(p=0.03)$ between the amount of financial resources expended and the years of study. The results revealed that more than half of the students in the first, second and third year spent between RM1-RM50 to purchase OTC medicines.

The study found that $70.7 \% \quad(n=340)$ of the respondents discontinued their medications. As to the reasons for discontinuance, $34.1 \% \quad(n=164)$ revealed that they discontinued using the medicines as prescribed as they felt that it was not effective. In contrast, $20.2 \% \quad(n=97)$ of the respondents cited side effects as their reason for discontinuance while $8.9 \%(n=43)$ of the students mentioned that they forgot the instructions. More than half $(n=288$; $59.9 \%$ ) of the respondents intimated that their conditions were not aggravated by their discontinuations.

Other types of self-medication practices discovered among female students in USM main campus were: $66.1 \%(n=318)$ of the respondents repeated their medications when the same symptoms recurred and $42.6 \%(n=205)$ of the respondents revealed that they normally repeated their prescriptions on recurrence of disease symptoms, while $12.1 \%$ of the students repeated their medications twice. Only $5.4 \%$ of the respondents repeated their medications 3 times or more.

The respondents were asked as to whether they took any left-over medicine obtained from relatives or friends. About one third $(n=163 ; 33.9 \%)$ of the respondents revealed that they always did so while $59.9 \%(n=288)$ of the respondents disclosed that they sometimes did so. There was a significant association $(p=0.015)$ between the consumption of left-over medicines obtained from relatives or friends and age groups and it is predominant among female students of the age groups between 19-24 years old. Similarly, there was a significant association $(p=0.001)$ between this behaviour and ethnicity, more high among Malay students.

As for the sharing of drugs, slightly more than half $(n=261 ; 54.3 \%)$ of the respondents admitted to sharing their medicines with friends and family members while $37.8 \%(n=182)$ denied doing so. There was a significant relationship $(p=0.037)$ between the sharing of medicines with friends and students' age group between 19-24 years old. Similarly, a significant relationship $(p=0.023)$ was detected between this behaviour and ethnicity, that Malay students, followed by Chinese students were more involved in this behaviour. Moreover, $22.1 \%$ $(n=106)$ of the respondents stated that they always purchased medications based on the recommendations of friends and relatives while $66.5 \%(n=320)$ mentioned that their medications purchases were sometimes premised upon the recommendations of friends and relatives. Table 2 reveals the main reasons mentioned by female students for practicing self-medication. More than half $(n=279 ; 58.0 \%)$ of those who practised selfmedication attributed the practice to their knowledge of their ailment and its treatment.

Table 2. Major reasons mentioned by female students for practicing self-medication $(n=481)$

\begin{tabular}{l|l} 
Reasons of self-medication practice & $\mathrm{N}(\%)$
\end{tabular}

What was the reason for practicing self-medication?

\begin{tabular}{l|l}
\hline Saves time & $69(14.4 \%)$
\end{tabular}

\begin{tabular}{l|c} 
Knowledge about disease and treatment & $279(58.0 \%)$ \\
\hline
\end{tabular}

Medication given by provider not effective $41(8.5 \%)$

Regarding self-medication using traditional herbal medicine, $63.0 \% \quad(n=303)$ of the respondents answered that they always used traditional medicine (herbal) to treat their ailments, while $16.2 \% \quad(n=78)$ students sometimes did so. Table 3 shows the main reasons mentioned by female students for using traditional herbal medicines. An estimation of the average sum the respondents expended on herbal medicines in relation to the total drugs purchased annually revealed that $44.5 \% \quad(n=214)$ of those surveyed spent between 1 to $10 \%$ of their pocket money to purchase traditional herbal medicines. In addition, $13.9 \% \quad(n=67)$ of the respondents spent between 11 to $20 \%$ of their money on herbal medications. There was a significant relationship between the use of traditional herbal medicines and age groups $(p=0.034)$.

\begin{tabular}{|l|c|}
\hline \multicolumn{2}{|l|}{$\begin{array}{l}\text { Table 3. Reasons of using herbal traditional medicine by } \\
\text { female students ( } \mathrm{n}=481 \text { ) }\end{array}$} \\
\hline Reasons for the use of herbal medicine & $\mathrm{N}(\%)$ \\
\hline What was the reason for using herbal medicine? \\
\hline Effective & $139(28.9 \%)$ \\
\hline Safe \& with fewer side effects & $81(16.8 \%)$ \\
\hline I belief in traditional-herbal medicine & $54(11.2 \%)$ \\
\hline Advice from friends and relatives & $34(7.0 \%)$ \\
\hline Easy to obtain (availability) & $32(6.7 \%)$ \\
\hline Cheaper & $22(4.6 \%)$ \\
\hline Unsure as to the reason why & $19(4.0 \%)$ \\
\hline
\end{tabular}

There was no significant difference $(p=0.128)$ between the total number of drugs found with students who practising self-medication and those who did not do so (Table 4). 


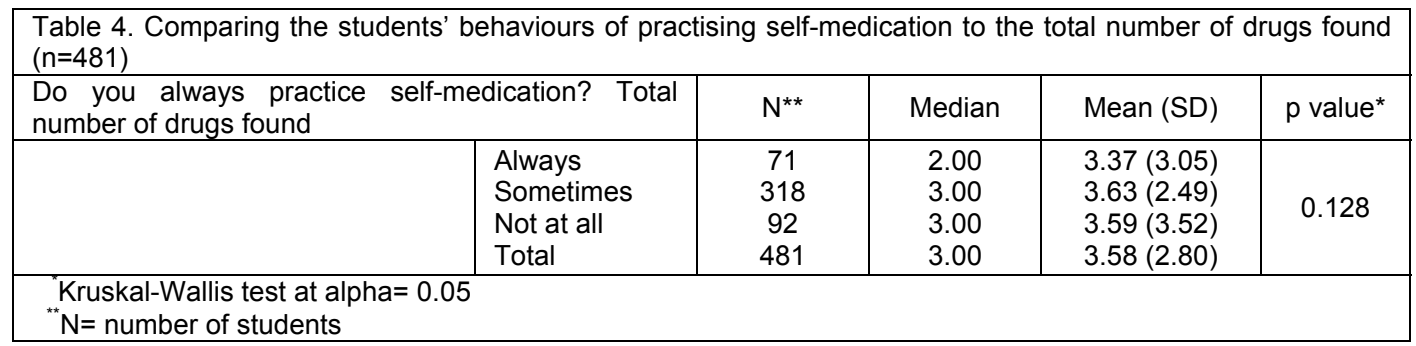

Of the total 481 respondents, slightly more than one fifth $(n=108 ; 22.5 \%)$ of the respondents cited ENT problems as the most common ailment they suffered from and treated while $19.6 \% \quad(n=94)$ mentioned respiratory diseases as the most common disease they experienced. Other ailments mentioned by single female students were hypertension, diabetes, epilepsy, urinary tract infection and joints disease.

\section{DISCUSSION}

It is noted that our participants belong to the well educated category of society and if the prevalence of self- medication is so high then the prevalence in the rest of the people may be an even more serious cause for concern.

This study found that majority of the female students kept medicines in their rooms with less knowledge of the indications of these medicines. Moreover, over half of all the students checked the drugs' expiration dates prior to consumption. These results are similar to those collated by researchers from Taiwan $^{16}$ who noted that among college students in Taiwan, the majority of the respondents in his study with a less satisfactory knowledge and safe practices in medication use which probably contributed to increased health risks and creating unnecessary economic burden. The study found the different types of medicines stocked by female students for emergency purposes were analgesics \& antipyretics, ENT drugs, vitamins \& minerals, GIT drugs, anti-infections and herbal medicines. They mentioned reasons like the need for pain killers every month, the need for vitamins for study; they usually use this sort of medicine for their disease while others mentioned they keep whatever medicine for future use.

Although many of the female students kept their medicines in their original packaged forms with their labels intact, but only few students placed their medicine in different packs or placed medications from several packs in a single container thus making it difficult to interpret tablets counts and identification of drug type especially in the accidental drug poisoning. The study also found that most of the students threw their expired and unused medicine into rubbish bins. This behaviour has its impact on the environment ${ }^{17}$ and the risks associated with the access to medications by children or pets. ${ }^{18,19}$ This can be a problem for the dump sites and the people getting exposed to these sites. Unfortunately, this problem is often less intensely taken and no one looks in to it seriously.
Nearly half of students asked dispensers in private community pharmacies and private clinics for OTC medicines while $43.0 \% \quad(n=207)$ sometimes asked dispensers for OTC. This may be attributable to the female behaviours of keeping medicine for common illness. $^{20}$ Such purchasing and retention of OTC medicine may lead to OTC medicine misuse due to a lack of knowledge about their use and contraindications. ${ }^{21}$ Basically, the OTC drugs were used as supplements or some other medicines to treat minor ailments. They consisted of nutrients and supplements (e.g. Ginseng, Gingko biloba, Evening Prime Rose, Protein Powder and Fish oil). A similar finding was reported by among university students in Turkey. ${ }^{22}$ OTC medicines also consisted of analgesics and fever medications (e.g. paracetamol and mefenamic acid) similarly to that were reported by among English university students, in addition they consisted of few cough preparations and some skin products. ${ }^{23}$ In this study, some of these medicines had to be purchased from other sources as they were unavailable in USM clinics. WHO ${ }^{24}$ reported that several case-control studies have related chronic renal failure to the use of analgesics like paracetamol, aspirin and other nonsteroidal antiinflammatory drugs (NSAIDs).

The study found that out of the students who discontinued their medication, around one third mentioned that their medicines were not effective, while approximately one fifth ( $n=97 ; 20.2 \%)$ mentioned their disuse was due to side effects. This finding was supported by another group of authors who noted that the two major reasons for discontinuance of medication was due to their ineffectiveness and their debilitating side effects. ${ }^{25}$ As for health consequences, many students said their health condition did not worsen due to discontinuation. This suggests the rest of the students need to consult their physicians if they experienced health problems due to discontinued drug usage since more information would increase patients' confidence in the drug and thus improve compliance. ${ }^{26}$

The different types of self-medications approaches involved the re-use of medications prescribed for similar symptoms that may recur in future. This may constitute a health hazard in the case of antibiotics, as misuse may lead to the development of antibiotic resistance. $^{27,28}$ In this study, more than half of the students consumed left-over medicines procured by relatives or friends while two third bought medicines based on the advice of relatives or friends. More than half shared medicines with their other friends while close to two third purchased and used traditional (herbal) medicines. Another study 
observed that sharing medicines was behaviour more common among girls $(20.1 \%)$ than amongst boys $(13.4 \%)$ and was more prevalent among girls in the 15-18 years old age group and the likelihood of sharing increased with age. It is plausible that this behaviour is wide spread in the USM main campus as students live in a closely knit community and are as such able to share anecdotes of their medication use. Moreover, students practice self-medication to treat minor ailments in order to save time (i.e., the longer waiting time for medical consultation during the visits to the USM Health Centre and panel clinics).

Among the students who practiced self-medication, more than half said that they did so because they knew their disease's symptoms and treatment while a small percentage did so to save time. The finding was of some similarity to that amongst first-year medical students of the Arabian Gulf University in Bahrain $^{29}$ where $44.8 \%$ disclosed that they practiced self-medication and the majority were female students who practiced self-medication.

Herbs are also used for self-medication by USM female students, similar to other developing countries. ${ }^{30,31}$ Herbal medicines are cultural factors in play, since the respondents had been born into a culture where herbal medicines would have been experienced from an early age and they believe in its power like modern allopathic medicines. ${ }^{32}$ Herbal medicines can easily be accessed in the medical shops. Of the students who used traditional medications, some said that they used traditional herbal medicines due to its efficacy while $16.8 \%$ $(n=81)$ of the students said they did so due to its safety and the incidence of fewer side effects when using these products. These reasons are also cited by a number of researchers as the leading cause for the use of complementary alternative medicines (CAM). For instance, a study from Singapore ${ }^{33}$ found that $62 \%$ of medical students at the faculty of medicine, National University of Singapore believed in the effectiveness of herbal medicine while $26 \%$ believed that this therapy was not harmful. Another survey from conducted at University of Newcastle and found that the using rate of CAM was $81.1 \%$ and that female students $(82.5 \%)$ used CAM practices at higher rates compared to male students $(77.2 \%)$. In fact, herbal medicine was used by almost one third $(37.3 \%)$ of Australian students and the main reasons cited were better results $(34.5 \%)$, preference for alternative medicine as new health patterns $(33.1 \%)$ and the incidence of fewer side effects $(32.1 \%) .^{34}$ Close to half of all students in this study who used herbal medicines spent between 1$10 \%$ of their own money for purchasing different types of herbal medicines. This finding is not surprising as the use of alternative medicine especially herbal medicine in Malaysia is a common socio-cultural behaviour among Malays, Chinese and Indians. ${ }^{32}$ Another factor that contributes to self-medication by herbal medicine was the influence of misleading advertisements as well as promotional pressure from drug promoters and peers who peddled vitamins and tonics (e.g. Gingko biloba, Ginseng) for a variety of alternative medicine producers.

In relation to this, the incidence of drug poisoning among female students in USM main campus was only $8.3 \%(n=40)$. Although this study did not relate these poisoning cases directly to the use of herbal medicine, but numerous studies on the adverse and toxic effects of CAM have been published and they reported this relation since herbs containing a wide variety of mostly unknown substances which may cause some unwanted side effects or even poisoning. $^{30,34,35}$

\section{CONCLUSIONS}

Prevalence of storage of unused medicines and self-medication behaviour amongst female students in USM is high. Stocking of medications was done irrespective of whether they were actually used and the proper storage methods and conditions were rarely observed. Analgesics \& antipyretics, ENT drugs, vitamins \& minerals, GIT drugs, antiinfections and herbal medicines were the drugs most common stored and used for self-medication. The findings of the study suggest the need for interventions that may include awareness programs for the university students, medicine refund policies and any other novel initiatives that could minimize the medicine storage and self-medication practices. The university should also come out with policies for waste disposal of expired and spoiled medicines since it can be hazardous to the environment and healthy living of the inhabitants.

\section{ACKNOWLEDGEMENT}

The authors would like to thank to all respondents who have agreed to participate in this study and to the management of Universiti Sains Malaysia who has allowed us to conduct this study in the campus.

\section{CONFLICT OF INTEREST}

The researchers would like to declare that there is no conflict of interest in this study.

\section{References}

1. Lee D. Drug utilization in Panama. Clin Epidemiol. 1991;44(Suppl 2):31S-38S.

2. Dong H, Bogg L, Rehnberg C, Diwan V. Drug policy in China: pharmaceutical distribution in rural areas. Soc Sci Med. 1999;48(6):777-786

3. Montastruc JL, Bagheri H, Geraud T, Lapeyre-Mestre M. Pharmacovigilance of self-medication. Therapie. 1997;52(2):105-110.

4. Figueiras A, Caamaño F, Gestal-Otero JJ. Sociodemographic factors related to self-medication in Spain. Eur J Epidemiol. 2000;16(1):19-26. 
5. Shankar PR, Partha P, Shenoy N. Self-medication and non-doctor prescription practices in Pokhara valley, Western Nepal: a questionnaire-based study. BMC Fam Pract. 2002;3:17.

6. World Health Organization. Global strategy for containment of antimicrobial resistance. WHO Communicable Disease Surveillance and Response (CSR), 2001 WHO/CDS/CSR/DRS/2001.2.

7. Zafar SN, Syed R, Waqar S, Zubairi AJ, Vaqar T, Shaikh M, Yousaf W, Shahid S, Saleem S. Self-medication amongst university students of Karachi: prevalence, knowledge and attitudes. J Pak Med Assoc. 2008;58(4):214-217.

8. Buke C, Hosgor-Limoncu M, Ermertcan S, Ciceklioglu M, Tuncel M, Köse T, Eren S. Irrational use of antibiotics among university students. J Infect. 2005;51(2):135-139.

9. Aljinović-Vucić V, Trkulja V, Lacković Z. Content of home pharmacies and self-medication practices in households of pharmacy and medical students in Zagreb, Croatia: findings in 2001 with a reference to 1977. Croat Med J. 2005;46(1):74-80.

10. Lau GS, Lee KK, Luk CT. Self-medication among university students in Hong Kong. Asia Pac J Public Health. 1995;8(3):153-157.

11. Grand AL, Hogerzeil HV, Haaijer-ruskamp FM. Intervention research in rational use of drugs: a review. Health Policy Plann. 1999;14:89-102.

12. Hardon A, Hodgkin C, Fresle D. How to investigate the use of medicines by consumers. Amsterdam: WHO;2004.

13. Abou-auda H S. An economic assessment of the extent of medication use and wastage among families in Saudi Arabia and Arabian Gulf countries. Clin Ther. 2003;25:1276.

14. Abahussain E, Matowe LK, Nicholls PJ. Self-reported medication use among adolescents in Kuwait. Med Princ Pract. 2005;14(3):161-164.

15. Ibrahim MIM. USM's Health -care system report, (unpublished), 2003.

16. Hsiao FY, Lee JA, Huang WF, Chen SM, Chen HY. Survey of medication knowledge and behaviors among college students in Taiwan. Am J Pharm Educ. 2006;70(2):30.

17. Park J. Pharmaceuticals in the environment and management approaches in Korea. Korea Environment Institute (KEI), 2005.

18. Anonymous. Establishing an unwanted medication collection program. Wisconsin / USA, Pharmacy Society of Wisconsin, 2007.

19. Lynne BYE. Dispose of unwanted medicines properly. In Waitemata District Health Board (Ed.) The University of Auckland, School of Pharmacy, 2007.

20. Dengler R, Roberts H. Adolescents' use of prescribed drugs and over-the-counter preparations. J Public Health Med. 1996;18:437-442.

21. Vallerand AH, Fouladbakhsh J, Templin T. Patients' choices for the self-treatment of pain. Applied Nursing Research 2005;18:90-96.

22. Ayranci,U, Son N, Son O. Prevalence of non-vitamin, non-mineral supplement usage among students in a Turkish University. BMC Public Health 2005;5:47.

23. French DP, James DH. Reasons for the use of mild analgesics among English students. Pharm World Sci. 2008;30:7985.

24. World Health Organization. The benefits and risks of self- medication: General policy issues. WHO Drug Information, 2000;14:1-2.

25. Paterson JM, Anderson GM. "Trial" prescriptions to reduce drug wastage: results from Canadian programs and a community demonstration project. Am J Manag Care. 2002;8(2):151-158.

26. Rother DL, Hall JA.Doctors talking with patients/ patients talking with doctors: Improving communication in medical visits, London, Greenwood Press, 2006.

27. Vanden Eng J, Marcus R, Hadler JL, Imhoff B, Vugia DJ, Cieslak PR, Zell E, Deneen V, McCombs KG, Zansky SM, Hawkins MA, Besser RE. Consumer attitudes and use of antibiotics. Emerg Infect Dis. 2003;9(9):1128-1135.

28. Datta A. Drug resistant bacteria, killer at large The Hindu- online edition of India's National Newspaper, 2001.

29. James H, Handu SS, AI Khaja KA, Otoom S, Sequeira RP. Evaluation of the knowledge, attitude and practice of selfmedication among first-year medical students. Med Princ Pract. 2006;15(4):270-275.

30. World Health Organization. Traditional medicine. In WHO (Ed.), 2003.

31. Forster DA, Denning A, Wills G, Bolger M, McCarthy E. Herbal medicine use during pregnancy in a group of Australian women. BMC Pregnancy Childbirth. 2006;6:21.

32. Mohd MA. Traditional medicines in Malaysia.Where are we heading? IPPP UM Research Bulletin, 2003.

33. Yeo AS, Yeo JC, Yeo C, Lee CH, Lim LF, Lee TL. Perceptions of complementary and alternative medicine amongst medical students in Singapore--a survey. Acupunct Med. 2005;23(1):19-26.

34. Feldman RH, Laura R. The use of complementary and alternative medicine practices among Australian university students Complementary Health Practice Review 2004;9:173-179.

35. Niggemann B, Gruber C. Side-effects of complementary and alternative medicine. Allergy. 2003;58:707-716. 